Journal of Agriculture, Food and Environment (JAFE)

Journal Homepage: http://journal.safebd.org/index.php/jafe

http://doi.org/10.47440/JAFE.2021.2117

Original Article

\title{
Investigation on the quantity and nutritional composition of slaughterhouse by- products of indigenous sheep
}

\author{
M. M. Billah, S. M. A. Islam, M. Khan* \\ Department of Animal Science, Bangladesh Agricultural University, Mymensingh-2202.
}

Article History

Received: 4 March 2021

Revised: 29 March 2021

Accepted: 31 March 2021

Published online: 31 March 2021

\section{*Corresponding Author}

M. Khan, E-mail: muckta.khan@bau.edu.bd

\section{Keywords \\ Sheep, Slaughterhouse by-products, Nutritive value, Yield, Age group}

\begin{abstract}
A B S T R A C T
The present study was done to find out the change of yield and nutritional composition of most edible slaughterhouse by-products of sheep with the change of age in Bangladesh. $\mathrm{T}_{0}=0$ tooth (under 1 year), $\mathrm{T}_{1}=2$ teeth ( 1 to 1.5 year), $\mathrm{T}_{2}=$ 4 teeth ( 2 years), $\mathrm{T}_{3}=6$ teeth ( 2 to 2.5 years), $\mathrm{T}_{4}=8$ teeth (more than 2.5 years) of sheep were the treatment groups. Live weight, warm carcass weight, dressing percentage, weight of by-products, proximate component of edible by-products for different age group of sheep were measured to conduct the experiment. Carcass weight, dressing percentage, by-products weight increased significantly with the increase of age except head. Among the nutritional differences, crude protein $(\mathrm{CP} \%)$ were found higher in liver and kidney than lung and brain. Ether extract $(\mathrm{EE} \%)$ were higher in liver and heart than kidney, lung, brain. Ash percentage were found highest at liver. $\mathrm{pH}$ level differed significantly in different age group. The weight of edible by-products (liver, lung, kidney, heart) increased with the increase of age except brain. These results will be helpful to realize the importance and change of yield and nutritive value of edible byproducts for different age group of sheep in Bangladesh.
\end{abstract}

() Society of Agriculture, Food and Environment (SAFE)

\section{Introduction}

A larger part of Bangladesh economy depends on agriculture. Among the four components of agriculture (such as crops, livestock, fisheries and forestry), livestock contributes in our national economy with vital roles, providing about $2.83 \%$ of gross domestic products (GDP) alone (BER, 2017). Indigenous sheep are one of the most popular species in Bangladesh for its very low feed demand, higher rate of prolificacy as well as disease resistance capacity (Hassan and Talukder, 2011). Number of sheep in Bangladesh is about 3.5 million (DLS, 2017) that is third in number among the ruminant species and mostly used for meat purpose. Except few crossbred, sheep of Bangladesh are mostly nondescript indigenous (Bhuiyan, 2006). As a subtropical country, breeding of indigenous sheep in Bangladesh is very common for the poor farmers with higher survival ability at harsh environment, low feeding practices and poor quality management. Thus, sheep plays an important role in the livelihood program and contributing by fulfilling the Millennium Development Goal (MDG).

USDA defined the animal by-products as the products harvested or manufactured from livestock other than muscle meat. It contains every single part of animal after slaughtering except dressed carcass. The animal by-products quantity can be calculated after subtracting the dressing percentage from 100. The meat industries of the world like to use the by-products of animal for reducing the human protein demand when compared the competition with plant protein sources. Utilization of by-products can also associate the meat industry more viable economically. Edible and inedible are the main classification of animal by-products depending on the use as food. An approximate amount of total animal by-products is about $60 \%$ on live weight basis where, $40 \%$ are edible and $20 \%$ are inedible (Chatli et al., 2005). Brain, liver, lung, kidney, heart are the most edible animal byproducts which are known as variety meat. Inedible byproducts includes skin, hides, ear, gallbladder etc.

Another classification of animal by-products are primary and secondary by-products (Sharma and Sharma, 2011). If byproducts are directly harvested from animal then those are called primary by-products and secondary by-products are prepared from primary by-products. For example, bone is a primary by-products where bone meal will be secondary byproducts. Depending on the ultimate use by-products can also be classified. Such as animal by-products for agricultural use (fertilizer, meat meal, bone meal etc.), byproducts for pharmaceuticals (pepsin, hormone, insulin, biochemicals etc.) (Sharma and Sharma, 2011). These kind of 
utilization will help to reduce environment pollution as well as nutritive supplement for livestock, crop and employment generation.

Nutritive value of edible animal by-products are very impressive in quality. In some case by-products nutrition is more than meat containing more amino acids, vitamin, minerals, hormones, fatty acids etc. Carbohydrate level is higher in some organ meat like liver, kidney than solid meat (Devatkal et al., 2004). Feet, tail, liver of animal contain protein level close to lean meat (Unsal and Aktas, 2003). Liver and kidney have higher amount of riboflavin (1.697$3.630 \mathrm{mg} / 100 \mathrm{~g}$ ) which is 5-7 times higher than lean meat. Niacin, vitamin B6, B12, A, folacin are found mostly in liver of animal. Kidney is an excellent source of vitamin Bcomplex. Good source of manganese (0.128-0.344 mg/100 $\mathrm{g}$ ) is found in liver. In sweetbreads and thymus, potassium level is $360-433 \mathrm{mg} / 100 \mathrm{~g}$ and phosphorus level is $393-558$ $\mathrm{mg} / 100 \mathrm{~g}$ (Devatkal et al., 2004).

The low fat level and protein source of mutton as red meat have a higher demand among the meat consumers in Bangladesh (James et al., 1997). However, the proper use and nutritive value of sheep slaughterhouse by-products is also unknown mostly. There is very few research work had been conducted regarding the amount and nutritional change of sheep slaughterhouse by-products at different age. Therefore, this study was conducted to investigate the change of yield and nutritional value of sheep by-products with the change of age as well as the price and use of these by-products.

\section{Materials and methods \\ Experiment site and duration:}

Different slaughterhouses of Mymemsingh had been selected to collect the sample. The duration of the study was six months including data and sample collection and laboratory analyses from March to August, 2018. These samples were collected from the following slaughter houses and markets:

1. Sutiakhali Bazar, Mymensingh

2. Kewatkhali Bazar, Mymensingh

3. K. R. Market, BAU, Mymensingh

4. Mymensingh Municipality Slaughterhouse, Mymensingh

Laboratory analyses were done at Animal Science laboratory under the Department of Animal Science, Bangladesh Agricultural University, Mymensingh.

Treatment groups according to the age and weight of indigenous sheep

Age of the sheep were estimated through dentition. The treatment groups were as following.

$\mathrm{T}_{0}=$ no pair permanent tooth (under 1 year)

$\mathrm{T}_{1}=$ one pair permanent teeth ( 1 to 1.5 years)

$\mathrm{T}_{2}=$ two pair permanent teeth ( 1.5 to 2 years)

$\mathrm{T}_{3}=$ three pair permanent teeth ( 2 to 2.5 years)

$\mathrm{T}_{4}=$ four pair permanent teeth (more than 2.5 years).

\section{Experimental Samples and data collection}

The data was collected through direct interview and making frequent personal visits. Before making actual interview, the objectives of the study were explained clearly to the butchers. Then the questions were asked in a very simple manner with explanation. The butchers were selected who were selling mutton and by-products to consumer, they were selected in order to achieve information. Therefore, total 25 butchers were randomly chosen for collecting data and sample in different market to satisfy the objectives. Firstly, all types of by-product (both edible \& inedible) such as heart, kidney, lung, brain, liver, head and skin were collected from 5 animals of each age group. Then most important edible by-products (heart, kidney, lung, brain and liver) were used for chemical analysis.

\section{Proximate Analysis}

The proximate components like Crude Protein (CP), Dry Matter (DM), Ash, Ether Extract (EE) of edible by-products (heart, kidney, lung, brain and liver) were carried out according to the methods AOAC (1995).

\section{pH Measurement}

The $\mathrm{pH}$ of those sample was done by following the method of Trout (1992). $25 \mathrm{ml}$ of distilled water and 5 grams of sample was homogenized by pestle and mortar and kept for 5-7 minutes. Then digital pH meter (Systronics, model 335) were used to record the $\mathrm{pH}$ of the suspension.

\section{Statistical Analysis}

MSTAT-C was used to analyze the data in one way ANOVA as per Completely Randomized Design (CRD). Means were considered significantly different for $(\mathrm{P}<0.05)$ and $(\mathrm{P}<0.01)$. Data presented are shown as means \pm SD (standard deviation).

\section{Results and discussion \\ Live weight, warm carcass weight, dressing percentage and weight of different by-products}

Table 1 presented the live weight, dressing percentage warm carcass weight, and weight of different by-products of indigenous sheep at different age group. Significant difference $(\mathrm{P}<0.01)$ were found in live weight, warm carcass weight and dressing percentage at different treatment group of indigenous sheep. Similarly, age effect on warm carcass weight were shown by Banerjee and Shanthi (2012) which was experimented on the meat quality and carcass of farmed elk. Weight of carcass of farm animal increased with the increase level of age and diet (Yagoub and Babiker, 2008). Highest live weight $(14.72 \pm 0.91) \mathrm{kg}$ was found in $\mathrm{T}_{4}$ age group and lowest $(8.39 \pm 0.04) \mathrm{kg}$ was observed in $\mathrm{T}_{0}$ age group. The carcass weight increased significantly $(\mathrm{P}<0.01)$ with increase of age and attained peak $(9.99 \pm 0.47) \mathrm{kg}$ at three pair permanent teeth $\left(\mathrm{T}_{3}\right)$. Dressing percentage also increased significantly $(\mathrm{P}<0.01)$ with increase of age. Dressing percentage was the highest $(67.95 \pm 2.11)$ for three pair permanent teeth treatment group and the lowest (51.25 \pm 1.23) was found in no pair teeth. Weight of different byproducts such as heart, kidney, lung, brain, liver and skin were found significantly $(\mathrm{P}<0.01)$ increased with the increase of age while the weight of head remain non-significant. As live weight, carcass weight and dressing percentage are positively increased with the increasing of age (Mashele, et al. 2017) and the offal weight are positively correlated to the live and carcass weight (Teye and Sunkwa, 2010), so weight of different by-products such as heart, kidney, lung, liver and skin were found significantly $(\mathrm{P}<0.01)$ increased with the increase of age. 
Table 1. Live weight, warm carcass weight and dressing percentage and weight of different by-products

\begin{tabular}{cccccccc}
\hline Parameter $(\mathbf{K g})$ & $\mathbf{T}_{\mathbf{0}}$ & $\mathbf{T}_{\mathbf{1}}$ & $\mathbf{T}_{\mathbf{2}}$ & $\mathbf{T}_{\mathbf{3}}$ & $\mathbf{T}_{\mathbf{4}}$ & P Value & Level of Sig. \\
\hline Live weight & $8.39^{\mathrm{c}} \pm 0.4$ & $9.71^{\mathrm{b}} \pm 0.38$ & $10.95^{\mathrm{b}} \pm 0.43$ & $14.7^{\mathrm{a}} \pm 0.96$ & $14.72^{\mathrm{a}} \pm 0.91$ & 0.001 & $* *$ \\
Carcass weight & $4.30^{\mathrm{c}} \pm 0.36$ & $5.76^{\mathrm{bc}} \pm 0.59$ & $6.68^{\mathrm{b}} \pm 0.41$ & $9.99^{\mathrm{a}} \pm 0.47$ & $9.98^{\mathrm{a}} \pm 0.39$ & 0.001 & $* *$ \\
Dressing \% & $51.25^{\mathrm{c}} \pm 1.2$ & $59.32^{\mathrm{b}} \pm 2.4$ & $61.00^{\mathrm{b}} \pm 1.5$ & $67.95^{\mathrm{a}} \pm 2.11$ & $67.80^{\mathrm{a}} \pm 2.23$ & 0.001 & $* *$ \\
Head & $0.99 \pm 0.02$ & $1.06 \pm 0.09$ & $1.11 \pm 0.09$ & $1.24 \pm 0.09$ & $1.39 \pm 0.11$ & 0.287 & $\mathrm{NS}$ \\
Brain & $0.22^{\mathrm{a}} \pm 0.32$ & $0.08^{\mathrm{c}} \pm 0.00$ & $0.09^{\mathrm{b}} \pm 0.00$ & $0.09^{\mathrm{b}} \pm 0.00$ & $0.09^{\mathrm{b}} \pm 0.00$ & 0.004 & $* *$ \\
Lung & $0.20^{\mathrm{b}} \pm 0.03$ & $0.19^{\mathrm{bc}} \pm 0.00$ & $0.22^{\mathrm{b}} \pm 0.02$ & $0.24^{\mathrm{ab}} \pm 0.03$ & $0.27^{\mathrm{a}} \pm 0.01$ & 0.001 & $* *$ \\
Heart & $0.18^{\mathrm{b}} \pm 0.00$ & $0.18^{\mathrm{b}} \pm 0.00$ & $0.18^{\mathrm{b}} \pm 0.00$ & $0.18^{\mathrm{b}} \pm 0.00$ & $0.23^{\mathrm{a}} \pm 0.03$ & 0.001 & $* *$ \\
Kidney & $0.15^{\mathrm{c}} \pm 0.00$ & $0.15^{\mathrm{c}} \pm 0.00$ & $0.17^{\mathrm{b}} \pm 0.00$ & $0.17^{\mathrm{b}} \pm 0.00$ & $0.18^{\mathrm{a}} \pm 0.00$ & 0.001 & $* *$ \\
Liver & $0.49^{\mathrm{c}} \pm 0.00$ & $0.50^{\mathrm{bc}} \pm 0.00$ & $0.51^{\mathrm{b}} \pm 0.00$ & $0.52^{\mathrm{ab}} \pm 0.00$ & $0.55^{\mathrm{a}} \pm 0.03$ & 0.001 & $* *$ \\
Skin & $1.44^{\mathrm{d}} \pm 0.08$ & $1.59^{\mathrm{c}} \pm 0.06$ & $1.71^{\mathrm{b}} \pm 0.04$ & $1.74^{\mathrm{ab}} \pm 0.05$ & $1.82^{\mathrm{a}} \pm 0.03$ & 0.001 & $* *$ \\
\hline
\end{tabular}

$\mathrm{T}_{0}=0$ Tooth (under 1 year), $\mathrm{T}_{1}=2$ Teeth ( 1 to 1.5 years), $\mathrm{T}_{2}=4$ Teeth ( 2 years), $\mathrm{T}_{3}=6$ Teeth $\left(2\right.$ to 2.5 years) and $\mathrm{T}_{4}=8$ Teeth (more than 2.5 years). Values are mean $\pm \mathrm{SD} *=5 \%$ level of Significance, $* *=1 \%$ level of significance, means with different superscripts within the row are significantly different.

\section{Proximate nutrients and $\mathrm{pH}$ value of most important} edible by-products of indigenous sheep

Different proximate components of edible by-products like lung, heart, kidney, brain, liver of indigenous sheep were analyzed. We found the lower value in case of young age of the animal that was increased with the increase of age.

\section{Liver}

Table 2 showed the proximate composition of liver. No significant variation was found for DM, EE and ash. DM percentage was relatively higher in $\mathrm{T}_{3}$ age and $\mathrm{EE}$ was found high at $\mathrm{T}_{4}$ group than other age group in liver. However, the $\mathrm{CP}$ and $\mathrm{pH}$ value variation were found significant among the treatments groups. Results of Okanovic et al. (2009) also supported this result where chemical characters were experimented for sheep and goat by-products processing. This findings were also almost similar to Adeniyi et al. (2011).

Table 2. Proximate nutrients and pH value of liver

\begin{tabular}{cccccccc}
\hline Parameters & $\mathbf{T}_{\mathbf{0}}$ & $\mathbf{T}_{\mathbf{1}}$ & $\mathbf{T}_{\mathbf{2}}$ & $\mathbf{T}_{\mathbf{3}}$ & $\mathbf{T}_{\mathbf{4}}$ & P Value & Level of Sig. \\
\hline DM $(\%)$ & $28.13 \pm 5.97$ & $26.15 \pm 7.07$ & $19.89 \pm 3.90$ & $31.21 \pm 6.01$ & $21.94 \pm 6.81$ & 0.222 & $\mathrm{NS}$ \\
$\mathrm{CP}(\%)$ & $17.01^{\mathrm{c}} \pm 0.07$ & $17.25^{\mathrm{b}} \pm 0.02$ & $17.64^{\mathrm{a}} \pm 0.08$ & $17.69^{\mathrm{a}} \pm 0.13$ & $17.89^{\mathrm{a}} \pm 0.07$ & 0.01 & $* *$ \\
$\mathrm{EE}(\%)$ & $14.28 \pm 5.22$ & $15.47 \pm 4.88$ & $12.62 \pm 6.11$ & $18.13 \pm 7.43$ & $21.73 \pm 8.38$ & 0.501 & $\mathrm{NS}$ \\
Ash $(\%)$ & $4.59 \pm 2.16$ & $4.06 \pm 0.87$ & $5.75 \pm 0.62$ & $3.39 \pm 0.53$ & $4.54 \pm 1.68$ & 0347 & $\mathrm{NS}$ \\
pH & $5.09^{\mathrm{c}} \pm 0.12$ & $5.95^{\mathrm{a}} \pm 0.19$ & $6.12^{\mathrm{a}} \pm 0.11$ & $5.37^{\mathrm{b}} \pm 0.25$ & $5.54^{\mathrm{ab}} \pm 0.51$ & 0.001 & $* *$ \\
\hline
\end{tabular}

$\mathrm{T}_{0}=0$ Tooth (under 1 year), $\mathrm{T}_{1}=2$ Teeth ( 1 to 1.5 years), $\mathrm{T}_{2}=4$ Teeth ( 2 years), $\mathrm{T}_{3}=6$ Teeth $\left(2\right.$ to 2.5 years) and $\mathrm{T}_{4}=8$ Teeth (more than 2.5 years). Values are Mean $\pm \mathrm{SD} * *=1 \%$ level of significance, means with different superscripts within the row are significantly different.

\section{Heart}

Table 3 presented the proximate composition of heart of sheep. DM was found higher in $\mathrm{T}_{3}$ and $\mathrm{T}_{0}$ than $\mathrm{T}_{1}, \mathrm{~T}_{2}$ and $\mathrm{T}_{4}$ in heart and that varied significantly. There were also significant differences in $\mathrm{CP}$, and $\mathrm{pH}$ value. But, non- significant $(\mathrm{P}>0.05)$ differences was found in EE and Ash. Hejnfelt and Angelidaki (2009) found nutritional composition of edible by-products of goat which was almost similar with our findings.

Table 3. Proximate nutrients and $\mathrm{pH}$ value of heart

\begin{tabular}{|c|c|c|c|c|c|c|c|}
\hline Parameters & $\mathbf{T}_{0}$ & $\mathbf{T}_{1}$ & $\mathbf{T}_{2}$ & $\mathbf{T}_{3}$ & $\mathbf{T}_{4}$ & P Value & Level of Sig. \\
\hline DM (\%) & $34.31^{\mathrm{a}} \pm 1.33$ & $25.27^{b} \pm 6.19$ & $19.22^{\mathrm{b}} \pm 4.80$ & $35.35^{\mathrm{a}} \pm 2.60$ & $19.69^{b} \pm 6.08$ & 0.022 & $*$ \\
\hline $\mathrm{CP}(\%)$ & $15.32^{\mathrm{b}} \pm 0.39$ & $15.50^{\mathrm{b}} \pm 0.16$ & $15.85^{\mathrm{a}} \pm 0.14$ & $15.54^{\mathrm{b}} \pm 0.52$ & $16.29^{\mathrm{a}} \pm 0.34$ & 0.04 & $*$ \\
\hline $\mathrm{EE}(\%)$ & $12.80 \pm 3.44$ & $14.62 \pm 1.16$ & $9.45 \pm 4.45$ & $13.52 \pm 2.78$ & $14.73 \pm 9.72$ & 0.728 & NS \\
\hline Ash (\%) & $2.21 \pm 0.82$ & $3.12 \pm 1.78$ & $4.64 \pm 1.07$ & $3.43 \pm 1.34$ & $2.68 \pm 1.06$ & 0.248 & NS \\
\hline $\mathrm{pH}$ & $5.85^{\mathrm{ab}} \pm 0.14$ & $5.62^{b c} \pm 0.10$ & $5.57^{\mathrm{bc}} \pm 0.34$ & $6.14^{\mathrm{a}} \pm 0.11$ & $5.36^{c} \pm 0.32$ & 0.017 & $*$ \\
\hline
\end{tabular}

$\mathrm{T}_{0}=0$ Tooth (under 1 year), $\mathrm{T}_{1}=2$ Teeth ( 1 to 1.5 years), $\mathrm{T}_{2}=4$ Teeth $\left(2\right.$ years), $\mathrm{T}_{3}=6$ Teeth $(2$ to 2.5 years $)$ and $\mathrm{T}_{4}=8$ Teeth (more than 2.5 years). Values are Mean $\pm \mathrm{SD} *=5 \%$ level of Significance, means with different superscripts within the row are significantly different.

\section{Kidney}

Table 4 showed the proximate composition of kidney of sheep. There were significant $(\mathrm{P}<0.01)$ differences in $\mathrm{CP}$ and $\mathrm{pH}$ and non-significant difference in DM, EE and ash percentage. Highest $\mathrm{CP} \%$ were observed in $\mathrm{T}_{3}\left(17.78^{\mathrm{a}} \pm\right.$
0.25). Similar results were also found by Okanovic et al. (2009) who showed the chemical composition of goat and sheep by-products. 
Table 4. Proximate nutrients and $\mathrm{pH}$ value of kidney

\begin{tabular}{cccccccc}
\hline Parameters & $\mathbf{T}_{\mathbf{0}}$ & $\mathbf{T}_{\mathbf{1}}$ & $\mathbf{T}_{\mathbf{2}}$ & $\mathbf{T}_{\mathbf{3}}$ & $\mathbf{T}_{\mathbf{4}}$ & P value & Level of Sig. \\
\hline DM (\%) & $19.5 \pm 3.49$ & $22.37 \pm 5.6$ & $21.6 \pm 5.44$ & $19.0 \pm 6.95$ & $20.9 \pm 7.22$ & 0.947 & $\mathrm{NS}$ \\
CP (\%) & $17.1^{\mathrm{b}} \pm 0.10$ & $17.1^{\mathrm{b}} \pm 0.23$ & $17.7^{\mathrm{a}} \pm 0.25$ & $17.78^{\mathrm{a}} \pm 0.25$ & $17.65^{\mathrm{a}} \pm 0.1$ & 0.002 & $* *$ \\
EE (\%) & $3.73 \pm 0.75$ & $5.53 \pm 0.92$ & $2.68 \pm 1.88$ & $2.77 \pm 2.24$ & $1.25 \pm 1.48$ & 0.068 & $\mathrm{NS}$ \\
Ash (\%) & $4.17 \pm 3.20$ & $2.15 \pm 0.83$ & $2.43 \pm 1.46$ & $4.41 \pm 3.21$ & $3.95 \pm 3.06$ & 0.732 & $\mathrm{NS}$ \\
pH & $6.33^{\mathrm{ab}} \pm 0.3$ & $5.49^{\mathrm{c}} \pm 0.13$ & $6.41^{\mathrm{a}} \pm 0.32$ & $5.57^{\mathrm{b}} \pm 0.33$ & $6.52^{\mathrm{a}} \pm 0.14$ & 0.001 & $* *$ \\
\hline
\end{tabular}

$\mathrm{T}_{0}=0$ Tooth (under 1 year), $\mathrm{T}_{1}=2$ Teeth ( 1 to 1.5 years), $\mathrm{T}_{2}=4$ Teeth $\left(2\right.$ years), $\mathrm{T}_{3}=6$ Teeth $(2$ to 2.5 years $)$ and $\mathrm{T}_{4}=8$ Teeth (more than 2.5 years). Values are Mean $\pm \mathrm{SD} * *=1 \%$ level of significance, means with different superscripts within the row are significantly different.

\section{Lung}

The result of proximate composition of lung are presented in Table 5. CP\% was relatively higher in $\mathrm{T}_{4}(15.98 \pm 0.15)$ than other treatments group. Significantly higher EE\% was obtained in $\mathrm{T}_{3}(3.22 \pm 0.32)$ than other treatment groups in lung. DM and ash percentage found non-significant. The CP percentage was increased with the increase of age of sheep, probably due to peribronchial collagen as well as total protein significantly increased with the increase of age of animals (Calabresi, 2007).

Table 5. Proximate nutrients and $\mathrm{pH}$ value of lung

\begin{tabular}{|c|c|c|c|c|c|c|c|}
\hline Parameters & $\mathbf{T}_{0}$ & $\mathrm{~T}_{1}$ & $\mathbf{T}_{2}$ & $\mathbf{T}_{3}$ & $\mathbf{T}_{4}$ & P Value & Level of Sig. \\
\hline DM (\%) & $19.87 \pm 4.82$ & $17.52 \pm 2.55$ & $18.63 \pm 6.94$ & $17.06 \pm 4.64$ & $17.64 \pm 3.14$ & 0.947 & $\mathrm{NS}$ \\
\hline $\mathrm{CP}(\%)$ & $13.78^{\mathrm{d}} \pm 0.09$ & $14.09^{c} \pm 0.13$ & $14.11^{\mathrm{c}} \pm 0.17$ & $15.34^{\mathrm{b}} \pm 0.16$ & $15.98^{\mathrm{a}} \pm 0.15$ & 0.001 & $* *$ \\
\hline $\mathrm{EE}(\%)$ & $1.15^{\mathrm{c}} \pm 0.35$ & $1.50^{b c} \pm 0.90$ & $2.73^{\mathrm{ab}} \pm 1.14$ & $3.22^{\mathrm{a}} \pm 0.32$ & $1.32^{b c} \pm 0.78$ & 0.026 & $*$ \\
\hline Ash $(\%)$ & $3.47 \pm 0.50$ & $1.89 \pm 0.49$ & $3.76 \pm 1.16$ & $3.11 \pm 1.72$ & $4.62 \pm 2.83$ & 0.38 & NS \\
\hline $\mathrm{pH}$ & $6.23^{\mathrm{a}} \pm 0.21$ & $5.52^{\mathrm{b}} \pm 0.29$ & $6.11^{\mathrm{a}} \pm 0.08$ & $5.66^{\mathrm{b}} \pm 0.14$ & $6.11^{\mathrm{a}} \pm 0.09$ & 0.002 & $* *$ \\
\hline
\end{tabular}

$\mathrm{T}_{0}=0$ Tooth (under 1 year), $\mathrm{T}_{1}=2$ Teeth ( 1 to 1.5 years), $\mathrm{T}_{2}=4$ Teeth ( 2 years), $\mathrm{T}_{3}=6$ Teeth ( 2 to 2.5 years) and $\mathrm{T}_{4}=8$ Teeth (more than 2.5 years). Values are Mean \pm SD. $*=5 \%$ level of Significance, $* *=1 \%$ level of significance, means with different superscripts within the row are significantly different.

\section{Brain}

Sheep brain proximate components are shown in Table 6. No significant change is found in DM, EE and ash percentage. $\mathrm{CP}$ percentage and $\mathrm{pH}$ varied significantly with age of sheep.
In case of $\mathrm{CP}$, highest value was found in $\mathrm{T}_{1}$ age. Lowest value was observed at $\mathrm{T}_{4}$ group. $\mathrm{pH}$ was highest in $\mathrm{T}_{4}$ group but lowest at $\mathrm{T}_{4}$ group.

Table 6. Proximate nutrients and $\mathrm{pH}$ value of brain

\begin{tabular}{|c|c|c|c|c|c|c|c|}
\hline Parameters & $\mathbf{T}_{0}$ & $\mathrm{~T}_{1}$ & $\mathbf{T}_{2}$ & $\mathbf{T}_{\mathbf{3}}$ & $\mathbf{T}_{4}$ & P Value & Level of Sig. \\
\hline DM (\%) & $21.46 \pm 9.08$ & $25.88 \pm 2.36$ & $20.53 \pm 2.41$ & $19.84 \pm 1.26$ & $23.11 \pm 1.68$ & 0.506 & $\mathrm{NS}$ \\
\hline $\mathrm{CP}(\%)$ & $14.06^{\mathrm{b}} \pm 0.09$ & $14.57^{\mathrm{a}} \pm 0.1$ & $14.28^{\mathrm{b}} \pm 0.15$ & $13.53^{c} \pm 0.2$ & $12.99^{\mathrm{d}} \pm 0.1$ & 0.001 & $* *$ \\
\hline $\mathrm{EE}(\%)$ & $4.42 \pm 2.09$ & $3.13 \pm 2.07$ & $7.05 \pm 1.61$ & $2.50 \pm 2.65$ & $4.50 \pm 2.83$ & 0.217 & NS \\
\hline Ash (\%) & $2.17 \pm 0.42$ & $3.97 \pm 0.20$ & $1.43 \pm 0.46$ & $2.43 \pm 0.52$ & $3.42 \pm 2.24$ & 0.093 & NS \\
\hline $\mathrm{pH}$ & $6.26^{\mathrm{a}} \pm 0.31$ & $5.61^{\mathrm{b}} \pm 0.02$ & $6.34^{\mathrm{a}} \pm 0.08$ & $5.83^{b} \pm 0.14$ & $6.45^{\mathrm{a}} \pm 2.24$ & 0.001 & $* *$ \\
\hline
\end{tabular}

$\mathrm{T}_{0}=0$ Tooth (under 1 year), $\mathrm{T}_{1}=2$ Teeth ( 1 to 1.5 years), $\mathrm{T}_{2}=4$ Teeth ( 2 years $), \mathrm{T}_{3}=6$ Teeth $(2$ to 2.5 years $)$ and $\mathrm{T}_{4}=8$ Teeth $(2.5$ to 3 years or more). Values are Mean \pm SD. $* *=1 \%$ level of significance, means with different superscripts within the row are significantly different.

\section{Comparison of proximate nutrients among different edible by-products}

The $\mathrm{CP} \%, \mathrm{EE} \%$, ash\% and $\mathrm{pH}$ value of edible by-products (liver, kidney, lung, heart, brain) had been represented in Figure 1, 2, 3 and 4 respectively. CP\% found slightly higher in liver and kidney but lower in heart, lung and brain. EE\% were higher in liver and heart but lower in kidney, lung, and brain of all age groups. Ash content was lower in brain, lung and kidney. $\mathrm{pH}$ value was varied in different edible by products.

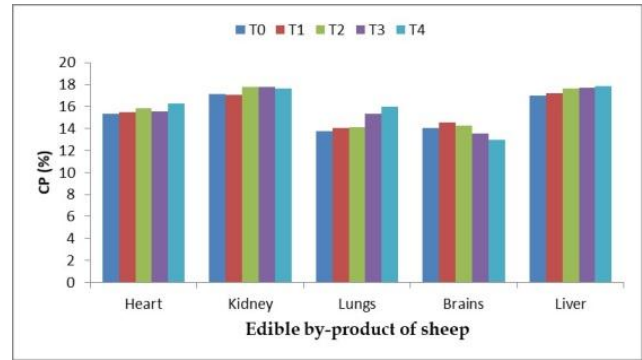

Figure 1: CP \% of edible by-products of sheep

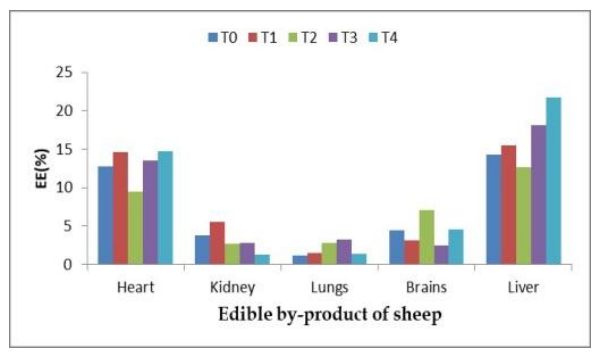

Figure 2: EE\% of edible by-products of sheep

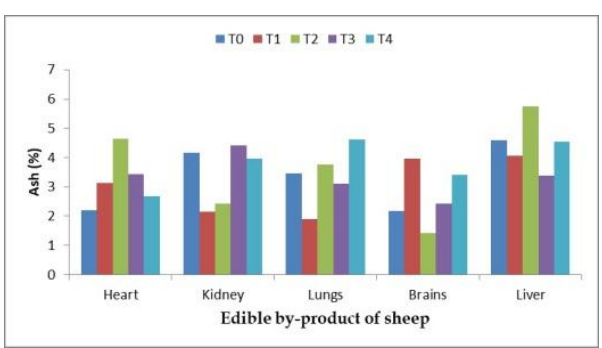

Figure 3: Ash\% of edible by-product of sheep

J. Agric. Food Environ. 2(1): 97-101, 2021 


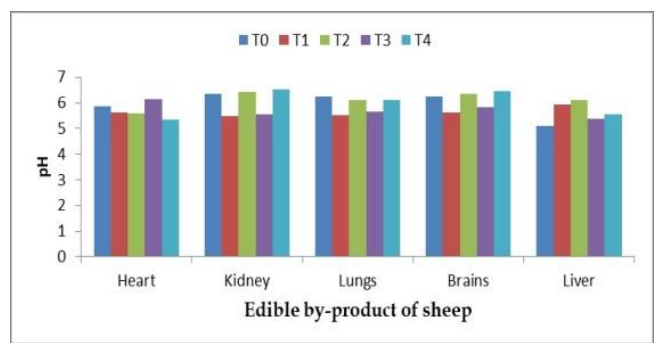

Figure 4: pH value of edible by-product of sheep

\section{Price and uses of the most edible by-products}

After comparing the weight and price of edible by-products of cattle and sheep, it was found almost similar level. However, the price variation was also observed at different region. Most of the cases price of liver was higher than the main products in butcher shop. Table 7 represented the price of edible by-products. By-products associates the butcher for extra revenue earning to cover the loss or extra income. That's why it is now important to evaluate the nutritional value of mostly edible by-products of sheep in Bangladesh.

Table 7. Price and uses of edible by-products

\begin{tabular}{|c|c|c|}
\hline $\begin{array}{c}\text { By- } \\
\text { products }\end{array}$ & $\begin{array}{c}\text { Price } \\
\text { BDT/Kg }\end{array}$ & Uses \\
\hline Liver & $480-530$ & $\begin{array}{l}\text { Liver is used usually as human food, } \\
\text { feed for pet animal (dog, cat) and } \\
\text { research purposes. }\end{array}$ \\
\hline Heart & $450-500$ & $\begin{array}{l}\text { Sheep heart is used generally for human } \\
\text { consumption, research purposes. }\end{array}$ \\
\hline Kidney & $450-500$ & $\begin{array}{l}\text { Human consumption and research } \\
\text { purposes. }\end{array}$ \\
\hline Lung & $380-420$ & $\begin{array}{l}\text { Human consumption, pet animal feed, } \\
\text { sold with meat. }\end{array}$ \\
\hline Brain & $520-580$ & $\begin{array}{l}\text { Human food, research purpose. It is sold } \\
\text { with head. }\end{array}$ \\
\hline
\end{tabular}

\section{Summary and conclusion}

The results of the present study can be summarized that age had great effect on the yield of inedible and edible slaughterhouse by-products of sheep in Bangladesh. Significant variation was found of different by-products percentage with the increase of age. Dressing percentage and warm carcass weight increased significantly with the increase of age. DM content found high at heart with the increase of age of sheep. CP increased in liver, heart, and lung but remained similar in brain and kidney.

\section{References}

Adeniyi OR, Ademosun AA, Alabi OM (2011). Proximate composition and economic values of four common sources of animal protein in South-western Nigeria. Zootecnia Tropical 29:231-234.

AOAC (1995). Official methods of analysis (16th ed.). Washington, DC, USA; Association of Official Analytical Chemists.

Banerjee P, Shanthi C (2012). Isolation of novel bioactive regions from bovine Achilles tendon collagen having
Billah et al., 2021

angiotensin I-converting enzyme-inhibitory properties. Process Biochemistry 47(12):2335-2346.

BER (2017). Bangladesh Economic Review, 2017. Finance Division, Ministry of Finance and planning, Government of the People's Republic of Bangladesh.

Bhuiyan AKFH (2006). Livestock genetic resources in Bangladesh: Preservation and Management, Icol services, Chinese Academy of Agricultural Science (CAAS), Beijing, China.

Calabresi C, Arosio B, Galimberti L, Scanziani E, Bergottini R, Annoni G, Vergani C (2007). Natural aging, expression of fibrosis-related genes and collagen deposition in rat lung. Experimental gerontology 42(10):1003-1011.

Chatli MK, Padda GS, Devatkal SK (2005). Augmentation of animal by-products processing for the sustainability of meat industry. Indian Food Industry 24(5):69-73.

Devatkal S, Mendiratta SK, Kondaiah N, Sharma MC, Anjaneyulu ASR (2004). Physicochemical, functional and microbiological quality of buffalo liver. Meat Science 68(5):79-86.

DLS (2017). Livestock Economy at a Glance (2017-18), Department of Livestock Services, Dhaka, Bangladesh.

Hassan MR, Talukder MAI (2011). Comparative performance of different regional native sheep in Bangladesh. The Bangladesh Veterinarian 28(2):85-94.

Hejnfelt A, Angelidaki I (2009). Anaerobic digestion of slaughterhouse by-products. Biomass Bioenergy 33:10461054.

James B, Lee CW, Park BK, Lee SM, Kwon EG, Im SK, Jeon GJ, Park YS, Hong SK (1997). Studies on growth performance and meat quality improvement of the unselected Hanwoo bulls in the performance test. Journal of Animal Science and Technology 52(5):427.

Mashele GA, Parker ME, Schreurs NM (2017). Effect of slaugter age between 5 to 14 months of age on the quality of sheep meat. In Proceedings of the New Zealand Society of Animal Production 77:177-180.

Okanovic D, Ristic M, Tasic T, Ikonic P, Popvic M, Gubic J (2009). Chemical characteristics of cattle slaughtering by-products for technical processing. Biotechnology in Animal Husbandry 25:785-790.

Sharma BD, Sharma K (2011). Outlines of Meat Science and Technology, Jaypee Brothers Med. Publ. Ltd. 360.

Teye GA, Sunkwa WK (2010). Carcass characteristics of tropical beef cattle breeds (west african shorthorn, sanga and zebu) in ghana. African Journal of Food, Agriculture, Nutrition and Development 10(7):28662883.

Trout GR (1992). Proc. 38th. Inter. Congr. Meat Sci. Technol., France. pp. 983.

Unsal M, Aktas N (2003). Fractionation and characterization of edible sheep tail fat. Meat Science 63(4):235-239.

Yagoub YM, Babiker SA (2008). Effect of dietary energy level on growth and carcass characteristics of cattle in Sudan. Tamilnadu Journal of Veterinary and Animal Science 7:102-106. 